\title{
Pessoas vivendo com HTLV: sentidos da enfermidade, experiência do adoecimento e suas relações com o trabalho
}

\author{
People living with HTLV: meanings of the illness, \\ experience of illness and its relationship with work
}

Maria Clara Leal Teixeira (https://orcid.org/0000-0002-3169-2607) ${ }^{1}$

Élida Azevedo Hennington (https://orcid.org/0000-0001-5280-8827) ${ }^{2}$

${ }^{1}$ Programa de PósGraduação em Saúde Pública, Escola Nacional de Saúde Pública Sergio Arouca (ENSP), Fundação Oswaldo Cruz (Fiocruz). R. Leopoldo Bulhões 1480, Manguinhos. 21041-210 Rio de Janeiro RJ Brasil. claralealtx@gmail.com ${ }^{2}$ Centro de Estudos da Saúde do Trabalhador e Ecologia Humana, ENSP, Fiocruz. Rio de Janeiro RJ Brasil.

\begin{abstract}
It is estimated that 2.5 million people are infected with the human T-cell lymphotropic virus (HTLV) in Brazil, mainly among afrodescendant populations with low socioeconomic status. The article presents results of the research that aimed to understand the illness experience of people living with HTLV, the ways of going about life and the relationships with work. Thirty-one semi-structured interviews were conducted with frequenters of an infectious diseases research institute. The oral narratives constituted the corpus that was analyzed using Sketch Engine software. Discourse analysis used references from Social Sciences, with emphasis on the health-work relationship. The manifestations of HTLV cause functional impairment and affect living standards, with repercussions on formal, informal, and domestic work. The narratives revealed complaints of physical symptoms and other health-related problems, in addition to prejudice, lack of family support and significant repercussions on work, namely issues aggravated by the absence of public policies aimed at people living with HTLV. The material, symbolic and subjective conditions caused by the progressive loss of physical capacity and early retirement affect not only the physical sphere, but also the psychic and social areas.
\end{abstract}

Key words HTLV, Illness experience, Discourse Analysis, Qualitative research, Occupational health
Resumo Estima-se uma prevalência de 2,5 milhões de pessoas infectadas pelo vírus linfotrópico de células Thumanas (HTLV) no Brasil, atingindo sobretudo populações negras e de baixo nivel socioeconômico. $O$ artigo apresenta parte dos resultados de pesquisa que objetivou compreender a experiência do adoecimento de pessoas vivendo com HTLV, os modos de andar a vida e as relações com o trabalho. Foram realizadas 31 entrevistas semiestruturadas com usuários de instituto de pesquisa em doenças infecciosas. A análise do discurso utilizou referenciais das Ciências Sociais e as narrativas orais constituíram o corpus analisado com o uso do software Sketch Engine. As manifestações do HTLV trazem prejuizo funcional e influenciam nos modos de andar a vida, repercutindo no trabalho formal, informal e doméstico. As narrativas evidenciaram queixas relativas a sintomas físicos e outros problemas de saúde além de preconceito, falta de apoio familiar e expressivas repercussões no trabalho. As condições materiais, simbólicas e subjetivas dos trabalhadores causadas pela perda progressiva da capacidade física e a aposentadoria precoce afetam não somente a esfera física, assim como a psíquica e social.

Palavras-chave HTLV, Experiência do Adoecimento, Análise do Discurso, Pesquisa qualitativa, Saúde do trabalhador 


\section{Introdução}

O vírus linfotrópico de células T humanas (HTLV, da sigla em inglês human T-cell lymphotropic virus) foi descoberto no início da década de 1980 e estima-se uma prevalência de 2,5 milhões de pessoas infectadas no Brasil, atingindo sobretudo populações negras e de baixo nível socioeconômico $^{1}$. Pesquisas estimam que a prevalência no país seja elevada especialmente nos estados da Bahia, Pará, Maranhão e Pernambuco ${ }^{2}$, mas não há ainda dados epidemiológicos conclusivos da soroprevalência nacional.

A transmissão ocorre via vertical, sexual ou parenteral. Fatores genéticos e imunológicos do hospedeiro são os principais responsáveis pelas manifestações clínicas associadas à infecção que podem ser neoplásicas, inflamatórias e infecciosas $^{3}$. Embora a maioria dos pacientes sejam assintomáticos, cerca de $2-10 \%$ dos infectados desenvolvem problemas de saúde, incluindo quadros neurológicos incapacitantes e outras doenças graves. O HTLV está associado a leucemia/linfoma de células $\mathrm{T}$ do adulto, mielopatia/ paraparesia espástica tropical e outras manifestações clínicas, tais como uveíte, artrite, dermatite infecciosa. O quadro mórbido é progressivo e insidioso e pode iniciar com fraqueza muscular de membros inferiores e espasticidade de graus variados que repercutem na locomoção, além de distúrbios esfincterianos e sensitivos ${ }^{4}$. Além da incapacidade progressiva, as pessoas que vivem com o vírus carregam consigo o estigma de uma infecção sexualmente transmissível (IST) ${ }^{5,6}$.

Os pacientes sintomáticos vivenciam alterações no cotidiano e na qualidade de vida por comprometimento no estado funcional e de sua saúde como um todo ${ }^{7,8}$. $\mathrm{O}$ vírus pode permanecer latente por décadas, mas parte dessas pessoas podem apresentar sinais e sintomas, comumente em faixa etária produtiva e as manifestações clínicas associadas ao vírus acabam por alterar a sua capacidade para o trabalho formal, informal e doméstico ${ }^{5,6}$.

A dificuldade ou impossibilidade laboral afetam o indivíduo e o coletivo na esfera psicossocial, especialmente os trabalhadores que não conseguem competir em condições de igualdade no mercado de trabalho. Tais indivíduos têm sentimento de culpa, fragilidade e inferioridade frente a seus pares devido à perda progressiva da capacidade de exercer sua função e de realizar atividades rotineiras, podendo culminar com a incapacidade total e aposentadoria precoce, sentindo-se rejeitados pela instituição, família e socialmente. No caso de pacientes do sexo masculino, as relações de poder perpassam a discussão de gênero numa sociedade patriarcal, em que homens ainda são idealizados como os provedores da família, enquanto no caso das mulheres, essas exercem tanto papeis de provedoras como atividades não reconhecidas socialmente, como de cuidado da família nuclear, da casa e de outros familiares. Frente a um mercado de trabalho precarizado e com pouca oferta de empregos, essas condições podem ser agudizadas num contexto de doença. Tudo isso ocorre numa sociedade que tem o trabalho como principal forma de inscrição social, que dignifica e dá identidade e lugar ao trabalhador ${ }^{9,10}$.

A infecção pelo HTLV ainda é pouco conhecida entre a população em geral e mesmo entre profissionais de saúde. Muitos pacientes permanecem assintomáticos, o que contribui para a transmissão silenciosa do vírus. Como vários quadros clínicos associados também podem ocorrer em pessoas não infectadas, a infecção do HTLV-1 passa frequentemente despercebida nos serviços de saúde. Não há tratamento específico para curar a infecção e o tratamento das doenças associadas restringe-se principalmente à sintomatologia. A prevenção da transmissão faz -se mister no controle, sobretudo em países em desenvolvimento nos quais as políticas públicas não priorizam o diagnóstico desta $\mathrm{IST}^{4}$. Apesar de ser considerada uma infecção endêmica no Brasil e do risco de transmissão vertical, não há controle pré-natal e a triagem sorológica é obrigatória e disponível somente para os doadores de sangue $^{11}$. De outro modo, há pouca visibilidade sobre a infecção pelo HTLV e as doenças associadas e ainda pouco se conhece sobre a experiência do adoecimento e as repercussões da infecção na vida das pessoas.

O objetivo do estudo foi compreender a experiência do adoecimento da pessoa com HTLV, pacientes de instituto de pesquisa em doenças infecciosas, seus modos de andar a vida e as relações com o trabalho. A pesquisa incluiu a investigação da trajetória das pessoas em busca de diagnóstico e cuidado, o convívio com as manifestações associadas ao HTLV e a perda ou redução da capacidade laborativa, com ênfase nas repercussões psicossociais e no processo saúde-doença-trabalho.

\section{Método}

Foram realizadas 31 entrevistas individuais semiestruturadas, gravadas e transcritas na íntegra. 
A amostra intencional de pacientes foi constituída de acordo com o comparecimento dos sujeitos ao serviço de saúde no período de 22/08/2018 a 09/10/2018. O final da seleção dos participantes ocorreu por saturação ${ }^{12}$.

As narrativas foram tratadas à luz da análise socio-histórica do discurso, que considera a linguagem na instância da enunciação, tendo em vista que textos são influenciados pelo tempo, espaço e relações de poder. Foram avaliadas as narrativas em primeira pessoa em busca de paradigmas exteriorizados na materialidade textual por meio de análise de corpus. A perspectiva analítica utilizada foi a da Análise do Discurso proposta por Orlandi ${ }^{13}$ que aborda as diferentes maneiras de significar, levando em conta a produção dos sentidos enquanto elemento da vida dos sujeitos. É uma perspectiva teórica que engloba na análise três campos do saber: linguística, psicanálise e marxismo. Assim, trabalha a língua, o sujeito e a história. Esta perspectiva analítica permite conhecer a capacidade do sujeito de significar e significar-se. A unidade da análise de discurso se constitui no corpus discursivo. Foi necessário entender como o texto se torna discurso e como este pode ser assimilado em conformidade das formações discursivas. Para a análise fez-se mister obter o objeto discursivo, ou seja, o material analisado, por meio do exame do material bruto - narrativas transformadas em texto linguístico como tal e pela análise de corpus se deu a "de-superficialização" desse material. Desta forma, foi possível chegar ao processo discursivo a partir da análise do objeto discursivo procurando determinar quais relações este estabelece com as formações sociais e ideológicas ${ }^{13}$.

As transcrições das narrativas orais constituíram o corpus analisado com ajuda do software Sketch Engine ${ }^{14}$. A pré-análise revelou palavras frequentes e direcionou a outros termos, emergindo uma série de enunciados a partir das repetições e dispersões nas narrativas. Tendo como base as categorias estabelecidas a priori e abordadas a partir do roteiro de entrevista ("experiência do adoecimento" "adoecimento e modos de andar a vida", "processo saúde-doença-trabalho”), os resultados encontrados na pré-análise indicaram novas categorias empíricas. Assim, o conteúdo das narrativas foi agrupado em dois eixos temáticos: "Repercussões do HTLV na vida da pessoa" e "HTLV, saúde e trabalho". A análise do discurso subsequente foi feita a partir da análise dos processos e das condições de produção da linguagem, estabelecendo relação entre a língua, os sujeitos e as situações produtoras do dizer, mediando o homem e sua realidade natural e social, fundamentado em referenciais das Ciências Sociais $^{13}$.

A pesquisa atendeu às exigências da Resolução no 466/2012, tendo sido aprovada pelo Comitê de Ética em Pesquisa da Escola Nacional de Saúde Pública Sérgio Arouca.

\section{Resultados e discussão}

A maioria dos entrevistados eram aposentados por invalidez, com idade média de 60 anos, mulheres, solteiras, pardas ou negras, de baixa escolaridade e cristãs. A partir da análise de corpus de narrativas orais foi discutido como as escolhas lexicais (frequência e qualidade) revelaram a experiência e as consequências do adoecimento em pessoas vivendo com HTLV. Foram analisados os termos "doença", "HTLV” e "trabalho" a partir de ocorrências e repetições tendo sido encontradas palavras e enunciados relacionados à família e religiosidade.

As principais narrativas, além dos sintomas físicos e as dificuldades atribuídas pelos entrevistados a eles, foram queixas sobre preconceito, falta de apoio familiar e de políticas públicas voltadas para as pessoas que vivem com HTLV, ausência de trabalho remunerado. Os discursos fizeram também forte referência a machismo, resignação e religiosidade.

O diagnóstico, em geral obtido após a peregrinação por vários serviços, impactou negativamente os entrevistados, bem como a família. Além do estigma por se tratar de doença infectocontagiosa e sexualmente transmissível, com a evolução da sintomatologia e o surgimento de limitações e incapacidades evidentes ao olhar somou-se o estigma da deficiência física. A discriminação e preconceito por ter uma IST eram vividos especialmente na família porque normalmente as pessoas que vivem com HTLV procuram ocultar a infecção e não revelam o diagnóstico fora do ambiente familiar. Por outro lado, devido à evolução e agravamento da doença, o surgimento de manifestações neurológicas e o uso de órteses e cadeira de rodas, é comum a discriminação e preconceito no contexto social associados à deficiência. Os próprios pacientes se sentiam inferiorizados e segregados, se viam como "deficientes" e "incapazes", um "peso" para as pessoas do seu convívio.

As limitações físicas com o tempo levam à falta de autonomia que os tornam dependentes de outras pessoas e de objetos como muletas, anda- 
dores e cadeiras de rodas, acarretando sentimentos de tristeza, menos valia, angústia e quadros mais graves de sofrimento e adoecimento psíquico como a depressão:

- Você pensa que essa tristeza é devido à doença?

- Não sei. É porque eu me sinto assim, pior do que as pessoas, quando as pessoas ficam me olhando eu fico morrendo de vergonha.

- Como foi a sua vida a partir da descoberta desse virus?

- A princípio eu fiquei meia... eu entrei meio em pânico, cheguei até a ficar... eu tinha tipo uma depressão, eu chorava à toa, acho que eu tava pensando muito e quando ia trabalhar e ficava mais sozinha, ficava sempre pensando como seria, né? E quando eu vi a cadeira pela primeira vez, aí que foi pior né, que aí, eu não quis conversar com ninguém ficava lá no meu canto, e sempre aquela coisa que dá, que aperta você, que dá de você ficar chorando sempre. Você não fala mais, você só chora, mas não bota pra fora. Meu problema foi esse, até hoje, mas continua assim, continua do mesmo jeito.

A autoimagem de um corpo antes hígido, de trabalhador, passa a ser a de um corpo doente, levando a um processo de luto pelo corpo saudável perdido, alterando não só a capacidade física, mas a própria identidade ${ }^{15}$. Condições e enfermidades crônicas e de longa duração, como a evolução do HTLV, com o surgimento de sintomas e doenças associadas que incluem dificuldade de deambulação, incontinência urinária, incapacidade física, uso de órteses e cadeira de rodas, tornam-se identidades de ser diferente, vergonha associada ao estigma e internalização de valores sociais depreciativos ${ }^{16}$.

O corpo visto como construção social faz com que a sociedade, através do trabalho, regule e imponha marcas, seus usos sociais e apropriação. O ideal para a reprodução e funcionamento das sociedades historicamente situadas é que os corpos sejam hígidos e saudáveis e no capitalismo, força de trabalho para produção de valor. Uma enfermidade que afeta a sobrevivência de uma pessoa no âmbito particular, também ameaça a sociedade, a coletividade ${ }^{16}$.

Mais da metade dos participantes da pesquisa estavam aposentados e destes, em sua maioria por invalidez, marcando a cronicidade e evolução da doença para a incapacidade, muitas vezes precoce. Embora a idade média dos entrevistados tenha sido de 60 anos de idade, a maioria das aposentadorias se deu devido à sintomatologia por HTLV e o agravamento do quadro clínico muitos anos antes. Ou seja, esses pacientes ainda se en- contravam em idade produtiva no momento da aposentadoria. A perda de capacidade de indivíduos em idade produtiva reflete diretamente na previdência social ${ }^{17}$ gerando altos custos sociais e econômicos para o país ${ }^{18}$ e mostra o impacto que o adoecimento pelo HTLV causa no âmbito da seguridade social e do mercado de trabalho.

As dificuldades no trabalho/emprego mais citadas foram devidas aos quadros álgicos e déficits motores. Além disso, muitos pacientes apresentavam sintomas urinários como incontinência, que dificultam o convívio social, culminando em infecções urinárias de repetição que os obrigavam a se afastar do ambiente de trabalho. Mesmo para trabalhos que não exigem esforço físico ou deambulação constante, aparecem complicações que acabam impedindo a continuidade da atividade como dor lombar mesmo que sentado, ou espasmos, formigamentos, fraqueza de membros inferiores, falta de equilíbrio:

- E esses sintomas que você me falou, eles atrapalharam o seu trabalho de alguma forma?

- Ah sim, com certeza, a incontinência mesmo, eu sempre andava com uma roupa extra, não tinha como, um lenço, pra se acontecer isso que acontecia pelo menos algumas vezes no mês... questão, já no final, que tinha que colocar o dedo lá pra marcar a pausa, pra marcar também entrada e saída, como não era assim na hora de ir embora ou de voltar e eu ter que levantar umas 6 vezes só pra marcar o dedo, ir lá na frente e voltar, de dez minutos ou então uns quinze minutos, já era um pouco cansativo pra mim, um fato também que não era nem distante o percurso do metrô até o prédio, cada vez eu sentia que tinha que andar mais devagar e parar em certos momentos, porque estava me cansando muito. Coisa que eu fazia em cinco minutos do metrô pro prédio, eu passei a fazer em dez, depois quinze e às vezes ia aumentando, então eu tinha que sair mais cedo de casa pra me dar tempo de ir, porque eu tinha que pegar lugar no metrô pra sentar. Pra voltar também era terrivel, duas horas, três horas da tarde, já não tem mais tanto lugar quanto de manhã e aí ficava mais difícil pra mim. Às vezes ficava pensando: "Ah, se eu não conseguir lugar vou descer na estação e descansar um pouco e depois vou no outro metrô". Então assim, com certeza, às vezes era antissocial, saía do trabalho pra casa, "gente não vou porque minha perna está doendo muito", nervoso que queria deitar, queria descansar, então, isso com certeza atrapalhou.

Eu tinha uma máquina minha de motor e eu pisava, hoje em dia se eu for costurar assim eu mexo um pouco com o meu pé mas fico um pouco mais atrasada, eu não gosto de pegar costura, eu 
não faço nada pra ninguém e nem eu tenho a máquina mais, eu vendi, né, foi necessidade, né [...] porque eu fiquei sem a máquina né, comprar outra, e perdi a força das minhas pernas.

Mesmo com a maioria de aposentados, todos os entrevistados relataram a importância do trabalho em suas vidas e o impacto da aposentadoria precoce, tanto no aspecto material quanto na subjetividade. Seja como dignificador, seja por questões financeiras, seja para preencher o tempo ou dar um sentido à vida, o trabalho mantinha a centralidade na vida dessas pessoas. São várias as narrativas dos indivíduos que desejariam continuar trabalhando e o relato dessa impossibilidade causou até choro durante a entrevista. Independência, sociabilidade através do contato com colegas de trabalho bem como a sensação de estar fazendo algo útil foram sentimentos positivos associados ao trabalho e relatados pelos participantes da pesquisa:

É muito bom o trabalho, sabe? Porque a gente trabalhando não depende de filho, nem de ninguém. Só daquele lá de cima, né? E outra coisa, a gente vai espairecendo, a gente dentro de casa pensa muita coisa.

Eu gostaria de trabalhar muito mais. As dificuldades de rua, de cadeirante, é ruim, entendeu? Eu não consigo trabalhar mesmo. Assim, meu sonho era trabalhar, entendeu, mas assim as coisas não mexem. Eu vejo cadeirante na rua que trabalha, mas ele vai pra baixo e pra cima, consegue rodar a cadeira, e eu não consigo fazer isso. Por causa do cansaço e falta de ar. E a limitação dos ombros.

[...] me deu a depressão no início, fiquei assim apavorada, sempre acostumada a trabalhar, ter minha vida, ter minha vida minha, entendeu? $E$ me ver sem poder trabalhar foi uma barra.

Em pesquisa sobre pacientes com Doença de Chagas, Marques e Hennington ${ }^{19}$ também evidenciaram narrativas que mostravam a insatisfação das pessoas pelo afastamento obrigatório do trabalho, sobretudo pelo caráter central que o trabalho ocupava em suas vidas. Além disso, o quadro da limitação física faz com que as pessoas com manifestações clínicas pelo HTLV fiquem mais restritas às próprias casas, percam o convívio do trabalho afastando cada vez mais os doentes de seu círculo social, num ciclo vicioso que se retroalimenta:

É monótono, né, porque eu fico o dia inteiro em casa, né... mal ou bem eram 6 horas de trabalho, era convívio com outras pessoas, às vezes aquele papo você não quer ir trabalhar, mas só o fato de que as pessoas convivem [...], mas eu sinto falta, até as coisas que eram bem chatas a gente começa a sentir falta.
Numa sociedade patriarcal, a inatividade masculina é menos aceita socialmente em comparação à feminina. Se aposentar, devido ou não à doença, modifica a vivência e identidade social do homem na medida em que leva a ficar parado um trabalhador ainda ativo ${ }^{16}$. No caso do adoecimento pelo HTLV, a perda do trabalho, além da perda financeira, implica na perda de sentido existencial:

O significado do trabalho pra mim? É o que me move né, é o que me faz manter vivo. Porque não é pelo dinheiro. Dinheiro ganha pouco mas você tá ali trabalhando, trabalhando e não dá tempo de ficar pensando em doença. [...] Agora, se você fica o dia todo parado olhando pro céu, você não tem sono, não tem nada.

Aposentar pra mim foi muito duro, entendeu? Muito duro. Ainda sinto muita falta da rotina, da sala de aula, daquilo tudo. De andar pra lá, andar pra cá. Pra mim foi muito duro, difícil.

Se o paciente sintomático que vive com HTLV é o provedor da família, a mudança de papéis sociais impacta esse grupo, pois o doente passa a ter condição de dependência e vulnerabilidade ${ }^{9}$. Por outro lado, se o paciente é do sexo masculino, afeta as relações de poder calcadas em gênero, numa sociedade em que o homem seria o responsável pelo sustento da casa. No relato abaixo, o entrevistado se considera "aquele que serve à família”, reforçando este estereótipo da identidade social de homem trabalhador. Para Canesqui $^{16}$, nessas representações de papéis sociais, as mulheres pouco toleram os homens no espaço da casa, ainda que adoecidos, por ser um espaço feminino, considerando a rua como o espaço masculino:

[...] Fico procurando coisa pra [fazer], porque a minha família é muito grande, por parte da minha mulher, são sete irmãs. Então ontem eu vim aqui, eu moro na zona oeste, vim aqui em Irajá pra poder fazer um favor, porque eu conheço bem o Rio de Janeiro e não tenho dificuldade. Mas pra uma mulher com uns 60 anos pra andar, resolver as coisas... então eu venho, quando tem uma coisinha, elas logo me pedem, eu sou aquele que sirvo à família, né? Eu fico procurando realmente coisa porque, pra não ficar em casa. Minha mulher sai pra trabalhar, vou ficar em casa, entendeu, apesar que eu não chego fácil às coisas, eu não tenho, entendeu, só eu e ela, eu não vou deixar a casa bagunçada também, né?

Apesar do HTLV, os entrevistados realizam atividades de trabalho, remunerado ou não, atividades domésticas ou na rua. Havia entrevistados que trabalhavam fora de casa, em geral, em 
empregos de baixa remuneração, no mercado formal ou informal, em atividades como costura, faxina, artesanato, contabilidade e serviços imobiliários. Até mesmo aposentados, alguns indivíduos continuavam trabalhando nesses setores. Quatro participantes estavam desempregados, alguns negavam a doença e almejavam um emprego:

Ah, me sinto muito mal, eu gosto de trabalhar né, gosto de fazer minhas coisas, eu acordo sete horas da manhã [...]. Eu faço qualquer coisa dentro de casa, eu faço, eu não paro não, quando eu tô parada é que eu tô doente mesmo, que esse vírus pra mim eu não tô com esse vírus, ele não me faz nada.

De modo geral, as limitações e dependência com frequência obrigam os indivíduos acometidos pelo HTLV a abandonarem o trabalho e outras ocupações que consideram prazerosas: nas entrevistas expressaram a vontade de continuar ativos e produtivos e a impossibilidade devido ao avanço da doença e às limitações físicas:

No Sarah [Hospital] mesmo, me ensinou a fazer fuxico. Não é fuxico de... [risos]. Eu gosto de costurar e consegui uma máquina. Mas as dificuldades foram tantas que eu não consegui levantar o braço [...]. De qualquer jeito, pra mim trabalhar eu preciso de alguém do meu lado o tempo todo. Entendeu? Porque tem cadeirante que vai no banheiro... assim, eu vou sozinha em casa, mas nos outros lugares que não tem. Eu preciso de uma babá, né, do meu lado.

Tomei vários remédios, vários. Fiquei vários dias em casa porque às vezes não aguentava ir trabalhar, tinha muita dor na coluna. Isso veio se agravando com muita frequência, a ponto de eu ficar desesperada e pedir pra sair do serviço.

Então não tava dando, há um tempo eu já havia conflitando até com a neuro a questão de ela cobrava que eu tinha que me tratar melhor e eu falava, chegou num ponto que eu falei: ou eu me trato ou eu trabalho. Aí não deu pra conciliar as duas coisas.

O trabalho doméstico foi pauta constante no discurso das mulheres entrevistadas. Mesmo as que usavam órteses ou cadeiras de rodas, referiam a realização de algum tipo de serviço doméstico. Outras mulheres residiam sozinhas e por não terem condições de contratar alguém para ajudar, acabavam por fazer o trabalho doméstico mesmo com todas as limitações físicas. Outras o faziam com ajuda de familiares ou amigos:

Se eu faço as coisas dentro de casa? Faço, faço... Assim, varrer casa? Faço, eu que faço tudo dentro de casa, no meu limite, o que eu posso. Aí quando é pra fazer faxina assim vai uma menina lá, faz de mês em mês que eu vou mantendo assim. Mas eu lavo prato, eu faço a comida, lavo a pia, lavo a casa, limpo assim o banheiro, mas essas coisas pesadas mesmo, não.

Para as mulheres, hoje as únicas provedoras em muitas famílias monoparentais, há repercussões na vida, na sobrevivência e no cuidado familiar:

Eu varro a casa, eu passo pano, boto pano na máquina, tiro da máquina com pauzinho, estendo, faço comida, faço tudo normal, na minha casa eu faço tudo. Minha filha mora comigo, ela estuda, aí eu faço tudo, lavo roupa, lavo tênis, faço tudo pra ela e ainda olho meu neto. Minha filha tá trabalhando, a minha outra filha é casada, então ela pagava pra olhar o menino. Agora quem olha o menino sou eu porque a menina tá boa, tá grande né, não dá trabalho, mas eu não cobro nada dela não, é minha filha mesmo, né?

Dois entrevistados solteiros relataram que ajudavam nos serviços domésticos, enquanto dos casados e em união estável, apenas um fazia este tipo de trabalho. Isso reforça a persistência das desigualdades de gênero em nossa sociedade, evidenciando que serviços domésticos são frequentemente assumidos como responsabilidade das mulheres. Este trabalho essencialmente doméstico não é remunerado, nem visto e muito menos reconhecido ${ }^{20}$. Além de causar desgaste, por ser invisibilizado e de pouco valor social, o trabalho doméstico pode estar associado negativamente à saúde psíquica das mulheres ${ }^{21}$.

Além das tarefas domésticas e do cuidado com a casa, marido e filhos, o serviço de cuidador de alguém da família é cada vez mais comum na nossa sociedade e, na maioria das vezes, a mulher ocupa este espaço. Foi bastante presente nas entrevistas a culpa de pacientes limitadas fisicamente pelo HTLV em não poder ajudar mais em casa ou dar assistência aos familiares que precisavam de cuidado. Este papel de gênero mostra a constituição das "relações afetivo-sexuais" familiares, ligado às expectativas sociais que a mulher esteja no papel feminino materno e de cuidadora da família ${ }^{22}$.

- Eu tenho minha mãe de noventa e oito anos que eu gostaria de poder participar mais do cotidiano dela, cuidar dela, mas infelizmente não posso. A minha irmã acha que eu deveria ser mais presente, mas eu não posso. Eu não tenho como, né, amor? Minha irmã cobra muito de mim essa parte. Eu até ajudo a pagar uma senhora pra cobrir a licença da empregada, do dia a dia dela [...]. Minha irmã acha que eu tenho que ir na casa dela botar um café pra ela. Eu não posso. 
- Você acha que sua irmã não entende suas limitações?

- Isso. Ela não entende. Outro dia ela ligou pra mim, pra eu ficar com mãe, mas eu não posso. A mãe mora numa escada, numa casa com dois lances de escada. Pra mim visitá-la meu filho me pega no colo, meu filho me leva, me tira do carro, me leva, me bota no sofá. Aí pra buscar: "Mãe liga pra mim hora que quiser embora, liga pra mim que eu vou aí te pegar". Meu filho me pega no colo, me bota no carro. Eu não tenho como cuidar da minha mãe, não tenho mesmo. Gostaria de participar, de cuidar dela, mas não tem como. Não tem como mesmo.

A questão da deficiência física como um obstáculo para a inserção no mercado de trabalho também foi presente nas narrativas. No exemplo abaixo, o entrevistado apesar de jovem, tem dificuldades em conseguir um trabalho por não parecer ser eficiente frente à deficiência. Fala também do julgamento dos outros quando se é jovem e sofre de uma enfermidade que pode comprometer o desempenho laboral e dificultar o acesso ao mercado de trabalho, caracterizando discriminação e estigma como uma identidade deteriorada ${ }^{5,23}$ :

Pô, não poderia esperar como a maioria dos pacientes, depois dos 40 que é mais tranquilo? As pessoas tendem muito a achar que quando você é jovem, você reage melhor à doença. Mas não é bem assim porque você fica com medo do futuro, fica com medo de piorar mais cedo do que aqueles que não tem idade avançada e você tem que entrar pro mercado de trabalho, e o mercado de trabalho, ele não olha com bons olhos uma pessoa que tem deficiência porque ele exige eficiência.

Sim, tem vários concursos que eu não vou poder fazer por causa de ter uma deficiência. Vários concursos que não vão abrir vaga simplesmente, que natureza do concurso exige que a pessoa não tenha deficiência. Então, carreira policial, não. [...] Existem carreiras que não abrem vaga porque a deficiência ela... veda.

Mesmo com as leis de inclusão de deficientes no país, as empresas privadas priorizam a contratação de indivíduos hígidos que apresentem habilidades desejáveis à função, representando um aspecto favorável ao aumento da produtividade, ou cujas limitações ou deficiências não exijam modificações estruturais no ambiente de trabalho ${ }^{24}$. Apesar da legislação favorável, a discriminação e o preconceito frente à deficiência permanecem presentes em nossa sociedade:

[...] No trabalho eu tive, e na última escola [também], eu tive um problema sério de receber um e-mail até falando que eu tava na cota de de- ficiente, que eu tinha que me adaptar ao trabalho, que a escola não poderia estar sujeita e que... enfim, um e-mail enquanto eu não tava aposentado.

Apesar das tentativas de inclusão das pessoas que vivem com deficiência ou alguma necessidade especial, a falta de conhecimento da sociedade faz com que a deficiência seja considerada impeditiva, um peso ou um problema por sua cronicidade e por restrições no desempenho de algumas funções ou mesmo por exigir mudanças nos ambientes de trabalho que irão gerar custos. Isso faz com que elas sejam discriminadas na sociedade e excluídas no mercado de trabalho ${ }^{25}$. O status estigmatizante coloca o indivíduo em uma posição diferente do restante da sociedade. O convívio com as dúvidas e incertezas, as dificuldades desde a escolarização até $\mathrm{o}$ acesso ao mercado de trabalho, a atribuição de ser "limitado" ou mesmo "diferente" expõe ao preconceito social e faz com que este indivíduo tenha seus projetos de vida redimensionados.

As pessoas sintomáticas que vivem com HTLV passam a ter uma representação de limitação, incapacidade e inutilidade de seus próprios corpos, uma vez que não são mais produtivos como eram antes ${ }^{15}$. As pessoas que vivem com limitações físicas são vistas como incapazes, improdutivas, lentas, desprovidas de qualidade e onerosas. É necessário pensar alternativas que permitam desconstruir esta imagem e criar o conceito de indivíduo capaz, produtivo, qualificado profissionalmente, apesar da deficiência. Isto favorece o estabelecimento de interações sociais tanto entre pessoas com limitações quanto sem limitações ${ }^{24}$.

\section{Considerações finais}

Hoje o campo da Saúde do Trabalhador tem sua visão ampliada para questões outrora secundarizadas. Também são considerados temas relevantes no campo o não-trabalho, o trabalho invisibilizado e marginalizado e o entrelaçamento do trabalho com marcadores sociais da diferença como classe, gênero, raça, deficiência. Nesse sentido, tanto as questões "macro" como as "microssociais", cotidianas, abordadas na perspectiva das Ciências Sociais, ganham vulto. O estudo ao trazer luz sobre o processo saúde-doença-trabalho de pessoas afetadas por doença infecciosa negligenciada e ainda pouco estudada sob essa perspectiva, contribui para a reflexão teórica e a produção de conhecimento no campo da saúde.

A compreensão dos desafios que envolvem o cuidado e a atenção integral aos pacientes que 
vivem com HTLV são referentes ao adoecimento e seus impactos na esfera física, psíquica e social. Aspectos relacionados à identidade do trabalhador, estigma e normas tradicionais de gênero se encontram entranhados na dinâmica da vida desses pacientes e refletiram a vivência da doença e seus modos de andar a vida.

As manifestações do HTLV trazem prejuízo funcional no trabalho, seja ele remunerado ou não, formal ou informal, doméstico e no cuidado familiar. A aposentadoria por invalidez, muitas vezes precoce, mostra que o HTLV impacta diretamente o trabalhador, na medida que o limita e o incapacita, retira esse indivíduo do mercado de trabalho ainda em idade produtiva e causa repercussões nas condições materiais de vida e na sua subjetividade. Já o trabalho doméstico ou de cuidado é afetado, sobretudo para as mulheres que são historicamente designadas para estes tipos de tarefa. Estar fora da condição para o trabalho entristece e influi na dinâmica simbólica, social e intersubjetiva dos pacientes. À medida que os sintomas surgem e avançam, aumenta a incapacidade e a dependência, ao mesmo tempo que repercutem na sociabilidade, impedindo ou diminuindo o convívio no trabalho e as relações sociais, fazendo com que fiquem mais isolados e restritos ao ambiente familiar. Muitos sofrem estigma e discriminação dentro da própria família. O corpo hígido e saudável dá lugar à incapacidade e deficiência. Com a evolução da doença e as restrições impostas pelo adoecimento e perda de autonomia, convivem com o tédio, o sofrimento e o sentimento de inutilidade.

O HTLV tem relevância epidemiológica no Brasil, mas ainda é pouco conhecido pela população em geral e até mesmo por profissionais de saúde. A infecção sem cura até o momento atinge principalmente pessoas de baixa renda, negras e moradoras nas periferias das cidades. Apesar dos avanços no conhecimento fisiopatológico da doença, ainda são poucas políticas públicas voltadas à prevenção, diagnóstico e atenção à saúde das pessoas afetadas pela doença no país, carecendo de ações ampliadas visando quebrar a cadeia de transmissão do vírus. Compreender a condição do paciente e suas necessidades poderá contribuir para sensibilizar a sociedade e demais atores responsáveis pela prestação de uma assistência integral e efetiva por parte dos serviços de saúde, para a necessidade de implementação de políticas públicas e a defesa de direitos.

\section{Colaboradores}

MCL Teixeira trabalhou na concepção, desenvolvimento da pesquisa e na redação do artigo. ÉA Hennington trabalhou na concepção da pesquisa, revisão e redação final do artigo. 


\section{Referências}

1. Carneiro-Proietti ABF, Ribas JG, Soares BCC, Martins ML, Melo GEB, Martins-Filho AO, Araújo AQC, Castro BG, Oliveira MSP, Proietti FA. Infecção e doença pelos vírus linfotrópicos humanos de células $\mathrm{T}$ (HTLV-I/II) no Brasil. Rev Soc Bras Med Trop 2002; 35(5):499-508.

2. Catalan-Soares B, Carneiro-Proietti ABF, Proietti FA. Heterogeneous geographic distribution of human Tcell lymphotropic viruses I and II (HTLV-I/II): serological screening prevalence rates in blood donors from large urban areas in Brazil. Cad Saude Publica 2005; 21(3):926-931.

3. Romanelli LCF, Caramelli P, Proietti ABF. O vírus linfotrópico de células T humanos tipo 1 (HTLV-1): Quando suspeitar da infecção? Rev Assoc Med Bras 2010; 56(3):340-347.

4. Verdonck K, González E, Van Dooren S, Vandamme A-M, Vanham G, Gotuzzo E. Human T-lymphotropic virus 1: recent knowledge about an ancient infection. Lancet Infect Dis 2007; 7(4):266-281.

5. Garcia IFS, Hennington ÉA. HTLV: uma infecção estigmatizante? Cad Saude Publica 2019; 35(11): e00005419.

6. Rivemales MCC. Vivência da sexualidade: representações sociais de pessoas soropositivas para o HTLV [tese]. Salvador: Universidade Federal da Bahia; 2013.

7. Coutinho IJ, Castro Filho BG, Lima J, Castello C, Eiter D, Grassi MFR. Impacto da mielopatia associada ao HTLV/paraparesia espástica tropical (TSP/HAM) nas atividades de vida diária (AVD) em pacientes infectados pelo HTLV-1. Acta Fisiatr 2011; 18(1):6-10.

8. Delazeri LM, Santos LR, Mendes SMD, Baptista AF, Sá KN. Impacto dos Aspectos Sociodemográficos e Clínicos na Qualidade de Vida de Portadores de HTLV-I com HAM/TSP. Rev Pesq Fisioter 2012; 1(2):43-55.

9. Orge G, Travassos MJ, Bonfim T. Convivendo com o HTLV-I. Gaz Med Bahia 2009; 1(79):68-72.

10. Ramos MZ, Tittoni J, Nardi HC. A experiência de afastamento do trabalho por adoecimento vivenciada como processo de ruptura ou continuidade nos modos de viver. Cad Psicol Soc Trab 2008; 11(2):209-221.

11. Zihlmann KF. Da invisibilidade à visibilidade do sujeito vivendo com a infecção/doença do vírus linfotrópico de células Thumanas do tipo 1 (HTLV-1) e o lugar das decisões reprodutivas nas tramas do saber e do cuidar [tese]. São Paulo: Universidade de São Paulo; 2009.

12. Fontanella BJB, Ricas J, Turato ER. Amostragem por saturação em pesquisas qualitativas em saúde: contribuições teóricas. Cad Saude Publica 2008; 24(1):17-27.

13. Orlandi EP. Análise de discurso: princípios e procedimentos. $8^{\text {a }}$ ed. Campinas: Pontes; 2009.

14. Sketch Engine. Copyright - Lexical Computing CZ sro [Internet]. 2019 [acessado 2018 mar 12]. Disponível em: http://www.sketchengine.co.uk/.
15. Gascón MRP, Santos RF, Capitão CG, Fantine-Nogueira MC, Oliveira ACP. Um corpo que perde o sentido: uma leitura psicanalítica dos pacientes com paraparesia espástica tropical. Rev SBPH 2013; 16(1):33-48.

16. Canesqui AM. "Pressão Alta" no Cotidiano: representações e experiências. Rio de Janeiro: Editora Fiocruz; 2015.

17. Sales RG. O déficit da Previdência Social: o impacto da aposentadoria por invalidez e sua abordagem na Reforma da Previdência. Rev Ambito Jurid 2017; 167:1-10.

18. Almeida GFP, Ribeiro MHA, Neto da Silva MAC, Castelo Branco RC, Pinheiro FCM, Nascimento MDSB Patologias osteomusculares como causa de aposentadoria por invalidez em servidores públicos do município de São Luís, Maranhão. Rev Bras Med Trab 2016; 1(14):37-44.

19. Marques AA, Hennington ÉA. As repercussões da Doença de Chagas no contexto de vida e trabalho de usuários de instituto de pesquisa. Saude Debate 2017; 41(n. esp. 2):215-224.

20. Hirata H, Kergoat D. Novas configurações da divisão sexual do trabalho. Cad Pesq 2007; 37(132):595-609.

21. Araujo TM, Pinho PS, Almeida MMG. Prevalência de transtornos mentais comuns em mulheres e sua relação com as características sociodemográficas e o trabalho doméstico. Rev Bras Saude Mater Infant 2005; 5(3):337-348.

22. Hirata H. O trabalho de cuidado. Rev Int Dir Hum 2016; 13(24):53-64.

23. Goffman E. Estigma e identidade social. In: Estigma: notas sobre a manipulação da identidade deteriorada. Rio de Janeiro: Ed. Guanabara; 1988. p.11-50.

24. Violante R, Leite L. A empregabilidade das pessoas com deficiência: uma análise da inclusão social no mercado de trabalho do município de Bauru, SP. Cad Psicol Soc Trab 2011; 14(1):73-91.

25. Maciel MRC. Portadores de deficiência: a questão da inclusão social. SP Perspectiva 2000; 14(2):51-56.

Artigo apresentado em 27/04/2020

Aprovado em 28/07/2021

Versão final apresentada em 30/07/2021

Editores-chefes: Romeu Gomes, Antônio Augusto Moura da Silva 
